\title{
AFFORDABLE HOUSING FOR YOUNG ADULTS IN LATVIA
}

\author{
Eliza SEKACE ${ }^{1}$, Janis VIESTURS ${ }^{2}$ \\ ${ }^{1}$ Riga Technical University, Riga, Latvia \\ ${ }^{2}$ Riga Technical University, Riga, Latvia \\ Corresponding author's e-mail: janis.viesturs@rtu.lv
}

\begin{abstract}
The topic is related to the need for housing as a social need for every member of society and its inaccessibility, mainly due to lack of finance. Housing affordability is a concept that indicates whether households are able to purchase or rent a home, maintain it and cover other non-housing expenses. Housing is one of the most important basic human values, but in the housing market, young households, whose incomes tend to be lower and more volatile, often face difficulties in finding affordable housing. For this reason, young adults are often considered high-risk tenants. Uncertainty in the rental market, restrictions on buying a home, and financial difficulties have a significant impact on young people's ability to buy or rent their own home and often lead to short-term renting and regular housing changes. Various events that have a significant impact on the national economy, e.g., the financial crisis, have affected all the population in different countries over time, but it is believed that these events have had the most significant impact on young people's living standards and on the level of housing affordability for youth. Therefore, it has been decided to evaluate the economic situation in the European Union, to analyse the socio-economic indicators for young people aged 20 to 34 years, and to study the concept of housing affordability both in Latvia and in the EU. The goal of the research is to analyse the possibilities of increasing the housing affordability for youth.
\end{abstract}

Keywords: Housing affordability, housing availability, housing market, youth.

JEL Classification: O18, R21, R28

\section{INTRODUCTION}

The availability of housing has declined worldwide in recent decades, especially for young adults. Younger generations in society are finding it increasingly difficult to access decent and suitable housing and have been affected by a variety of factors. It is, therefore, necessary to carry out a study on how to increase the affordability of housing among young people.

The concept of housing affordability varies based on location and context (Bergenstråhle, 2018) and it does not have a single, precise, and appropriate definition that applies to all members of society. Affordable housing in a wider meaning could be housing that is affordable for the maximum demographics, which indicates different levels of income groups (Pittinii, 2012). However, the concept of affordable housing is defined in many ways on the basis of different classifications, and ranges from relative, subjective, affordability, repayment and income availability (Gan, Hill, 2009). 
The concept of housing affordability tends to be relative and context-sensitive, measured against other economic variables such as purchasing power, GDP, etc. (Pittinii, 2012). The most common notion of affordable housing implies that households that spend more than $30 \%$ of their gross income (Linneman, Megbolugbe, 1992) to obtain adequate and appropriate housing have an affordability problem, i.e., the most common approach to define housing affordability is to consider the percentage of income that a household spends on housing costs (Pittinii, 2012).

Analysing the real estate rental market, it is necessary to separate the youth housing market, in which tenants are characterised by short-term, often unstable income and frequent housing changes, which are clearly different from the common housing market (Schelkshorn, 2018). It is pointed out that it is important to study the socio-economic indicators for young adults in order to find the most economically advantageous solution for increasing the affordability of housing for young adults in the EU. In order to analyse the concept of housing affordability as precisely as possible, it should be explained in terms of social, economic and political aspects within the present study. The availability of housing is affected by a variety of aspects, so its evaluation and analysis must take into account many factors that affect it both externally and internally.

Based on different sources of information, the youth or the age group of young adults is divided differently. In order to analyse the specific age group more precisely, it should be defined. Based on Erikson's research, youth is a stage between the ages of 19 and 39 (Erikson, 1975). The Federal Interagency Forum on Child and Family Statistics describes young adults as individuals aged 18-24. The United Nations, however, defines youth as persons aged 15 to 24. According to the Massachusetts Institute of Technology (MIT), young adulthood is generally defined as 18 to 22 or 18 to 25 and Bleyer WA defines the older adolescent-young adult age range as 15 to 29 years of age (Bleyer, Albritton, 2003).

Within the framework of the present research, it has been concluded that not only the availability of housing is not defined as one specific concept, but also the age group of young adults.

As the study mainly analyses statistical data, the age group is used as it is defined in statistical databases. The age groups of the Eurostat statistical data are divided into different groups, both according to the working age of the population and the age group of young adults. In the statistical databases that compile data on the EU, the age group of youth is repeatedly determined to be exactly 20-34 years old. This age group is defined as young adults. This age group is indicated both in the EU statistical database Eurostat and others, e.g., in the official statistical database of Spain (Spanish - Instituto Nacional de Estadística). Also, available statistics for the USA divide youth into three age groups of 20-24, 25-29, and 3034 years.

As mentioned before, in the course of the study, information has mainly been obtained by compiling the available statistical data from different statistical databases, e.g., the data of the Central Statistical Bureau database and the information available in them, the EU statistical databases, as well as other 
statistical data sources, theoretical books, scientific articles and various studies related to the housing market.

\section{HOUSING AFFORDABILITY}

In modern society, the transition of young people to their own housing is often a complex process due to the interrelated nature of the housing market and youth income inequality. The availability of housing, especially for young adults, has declined worldwide in recent decades (Bergenstråhle, 2018). The younger generations in society are finding it increasingly difficult to access decent and suitable housing and have been affected by a variety of factors. These factors include policies leading to declining housing affordability associated with greater market dominance of housing systems, increase in the number of temporary jobs, longer periods of full-time education, and growing economic instability and uncertainty (Forrest, Yip, 2012), but stable housing is essential for the development of young people. Young people moving from their parents' home usually experience a variety of housing problems and often find unstable or temporary housing (Munson, Stanhope \& Small, 2017).

The concept of affordable housing is highly relative (housing affordability through history) and subjective (classic assumption of the individual with their rational self-interest) at the same time, and its usage may depend on the locality (Aslam, Zull, 2019; Cai, 2017). Since the definitions of affordable housing vary based on location and context, the measurement of it is also found to be complex and difficult. In most of the cases, housing affordability is measured by the expenditure on housing versus the income of the household (Gopalan, Venkataraman, 2015). This is one of the commonly used housing affordability parameters based on the expenditure or ratio method, i.e., housing affordability is often measured by the ratio of median housing prices to gross annual median household income, otherwise known as the median multiple.

While housing is considered affordable for most people in the EU, buying a property or having a tenancy agreement is not enough for housing to be affordable (Adabre, 2020). Housing then has to be maintained in good technical and visual condition by the owner or tenant, but it obviously consumes additional financial resources from household income.

Often, most housing expenditure is not rent or mortgage payment, but housingrelated expenditure (Eurostat statistical database, 2019). It was accounted that the housing-related expenditure was the largest share of the total household expenditure in the EU countries in 2017 - on average $22.3 \%$ of household final consumption expenditure.

Affordability is, as mentioned before, a relationship between housing and people/households (Bergenstråhle, 2018) and it is a concept that indicates whether households are able to purchase or rent a home, to maintain it and cover other nonhousing expenses. The concept of housing affordability is the percentage of total household income spent on housing. Housing expenses that exceed $30 \%$ of household income have been viewed as an indicator of a housing affordability problem (Pittinii, 2012). This 30-percent of income standard is a widely used and 
accepted measure of the extent of housing affordability problems. While simple and easy to implement, the measure is not perfect. However, according to the Eurostat statistical database, the indicator of the housing cost overburden rate is defined as the percentage of the population living in a household where the total housing costs (net of housing allowances) represent more than $40 \%$ of the total disposable household income (Bergenstråhle, 2018). In the statistical database, the burden of housing-related costs is defined as a percentage of the household total income, where total housing-related costs represent more than $40 \%$ of the total disposable income of the household, but this is a highly incorrect approach for analysing housing affordability. A solvent household will have much more money left to cover its housing costs than just the necessary non-housing expenses, even if it costs the household more than $40 \%$ of its disposable income. On the other hand, a poor household may not have sufficient financial resources to cover significant nonhousing expenses after housing expenses have been paid, even if these expenses account for only $30 \%$ or even less of disposable income.

One of the definitions of housing affordability is as follows: "Housing is available if the household income is the accepted minimum standard and can maintain housing, leaving sufficient income to cover significant non-housing expenses" (Stephens, 2010). Sufficient income to cover significant non-housing expenses is often referred to as the minimum income standard. This definition is called the concept of residual income. It is considered that this definition and calculation are also very imprecise, given the significant difference between, for example, the minimum monthly wage and the average wage in the country, e.g., the minimum wage in Latvia in 2019 was $430.00 €$ before taxes, while the average wage in Latvia in the 3rd quarter of 2019 was $1091.00 €$ before taxes.

This means that a more appropriate definition would be that housing is considered to be available if the household can afford and maintain an acceptable level of housing, leaving the household with a sufficient income to cover significant non-housing expenses. Stone also used a relatively different approach to measuring housing affordability. For example, he considered housing to be affordable if, after meeting the price of housing, people can still meet non-housing household demands at a basic level of adequacy (Stone, 2006; Bergenstråhle, 2018). Advocay has defined affordable housing as the one that "... is available at a cost that does not compromise a household's ability to attain other basic needs of life, including the need for food, clothing, and access to education" (Advocay, 2019). This definition, as Stone's and Bergenstråhle's, of affordable housing not only considers the price and ability of the households to pay but also reiterates the importance of having some other basic amenities (Advocay, 2019).

The affordability of housing, more specifically - opportunities to pay more for housing, is a common issue not only among young people. Other generations also face problems when the cost of buying or renting a house is disproportionately high compared to their household income. Similarly, housing maintenance fees often cause financial difficulties for households. However, it is pointed out that it is very important for residents aged 20 to 34 to find their first independent residence, as instability in the labour market, the real estate market and the rental market create additional difficulties in finding affordable housing. The affordability of housing 
depends on many different factors. It has been proven that the level of education and the availability of work are two of the main factors, which influence affordable housing for young adults. However, employment for young adults cannot be successful without prior access to stable, secure, and suitable housing. Housing has a multidimensional significance for accelerating economic growth and ensures the well-being of the people. To highlight how important affordable housing is, Mohan stated that "...future national competitiveness and economic success will depend on the comparative efficiency of cities. Because housing is where jobs go to sleep at night, the quantity, quality, availability, and affordability of housing become a key component in national economic competitiveness" (Mohan, 1992).

The number of young adults, aged 20-34 years, in the European Union is around 92.6 million, so it is believed that it is very important to study the issue of access to housing for this age group, as it is often the stage of starting a family, buying the first dwelling or moving to a private house. However, young people often find themselves in a situation where, for various social or economic reasons, they find it difficult not only to buy but also to rent a dwelling (EU publications office, 2011). It is believed that this topic is highly relevant nowadays, because the number of people in the world is growing, while the indicators of housing affordability are not - due to both financial considerations and overcrowding.

\section{Socio-Economic Indicators of Youth}

It is considered important to analyse the youth housing market and housing affordability separately from the overall rental market, as the youth housing market is defined as volatile. The transition of young people from their parents' home to their own housing is defined as an intermediate or transitional stage. The reasons and consequences of the unavailability of youth housing vary from location to location, but there are general trends that affect young adults in many cities:

- many young adults tend to stay longer in their parents' house for economic reasons;

- nowadays young people are more dependent on the private rental sector;

- young people need to spend more of their income on housing (including rent) when they live independently (Schelkshorn, 2018).

One of the main problems for young adults is a high level of unemployment. The unemployment rate of youth is higher than an average unemployment rate in the EU. It depends on various factors, such as a person's age, level of education and integration into the labour market. Youth unemployment is considered to be an important issue for the development of both the state and society.

The unemployment rates for young adults by age groups and their educational attainment level are shown in Fig. 1. 


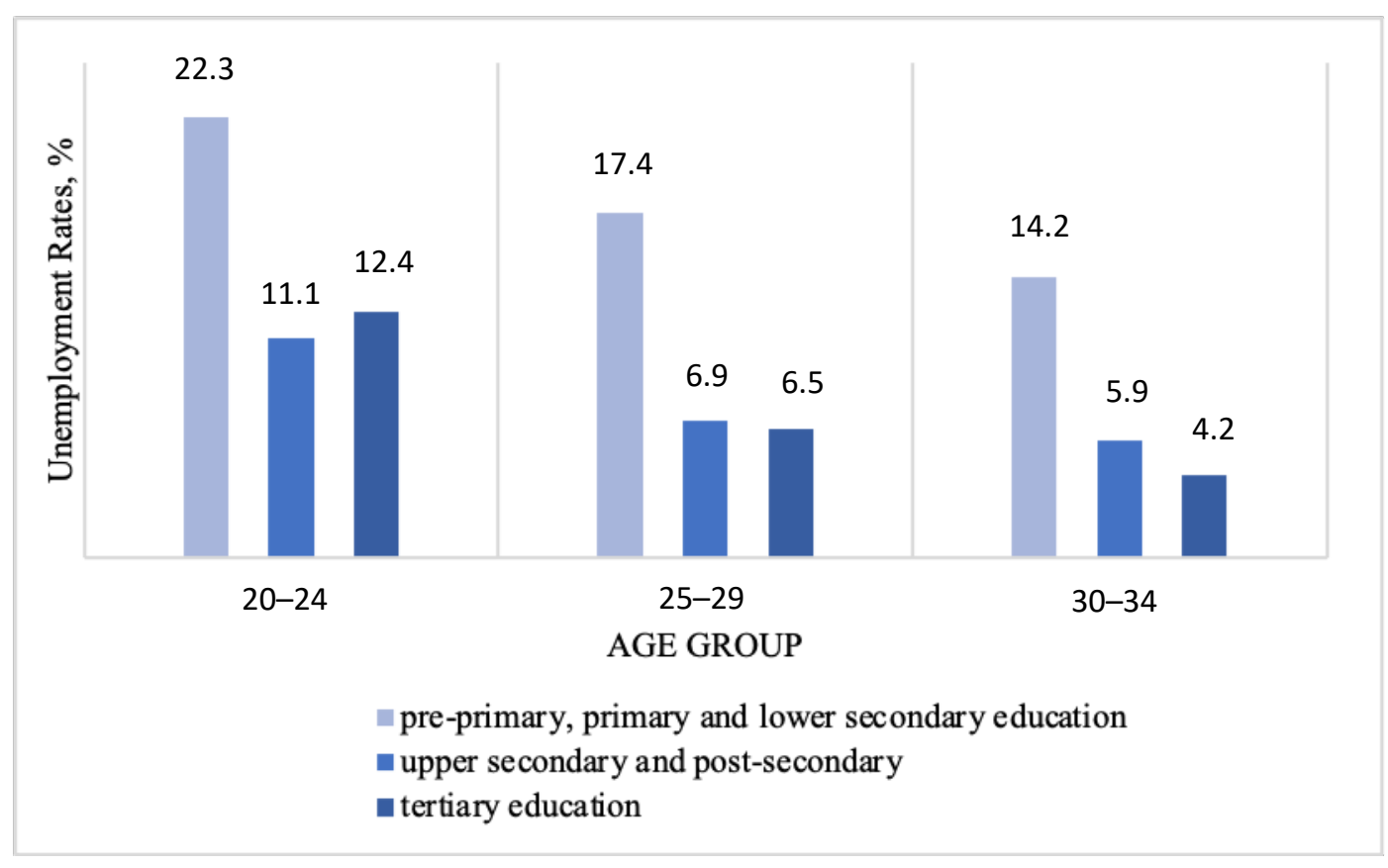

Fig. 1. Unemployment rates by age and educational attainment level in the EU, 2019.

The level of education is important, but it is not the main factor for securing employment. For young adults in the age group of 20-24 years with the same education as young adults in the age group of 30-34 years, the unemployment rate is almost three times higher. For persons aged 30-34 years, the unemployment rate is the lowest. However, there are significant changes in the unemployment rate, depending on the person's level of education. The data show a tendency that the unemployment rate is directly related to a person's level of education. Often, tuition fees are the reason why young people choose not to raise their level of education. The fee for obtaining higher education, of course, depends not only on the country where it is obtained, but also on the chosen field of study. Often, young people need a study loan or other financial loans to obtain higher education, because they need relatively large financial resources to obtain education. This is a problem faced by young people all over the world, not just in the EU. Ten percent of 2,000 people surveyed by the Bank of America said they had not bought their housing because of student loan debt. The average price for higher education in the Baltic States is provided in Table 1 .

Table 1. Average Tuition Fee in the Baltic States (EUR)

\begin{tabular}{|l|l|l|l|}
\hline Degree & Latvia & Lithuania & Estonia \\
\hline Bachelor studies & $968-3557$ & $1000-5300$ & $1660-7500$ \\
\hline Master studies & $1000-5333$ & $2200-6500$ & $1660-7500$ \\
\hline
\end{tabular}


Tuition fees often prevent young people from getting their dwelling. First, the state must ensure that all young people have equal opportunities to leave the parents' home and live independently. This requires a better understanding of the political, economic, social and cultural factors that limit the transition of young people and would require significant changes in policy issues. The second key challenge is to improve the suitability and accessibility of housing for young people. Homeowners and builders should try to offer housing that is better suited to young people - apartments that can be shared by several students (Billari, Liefbroer, 2010).

While the employment rate is a very important factor, the wages received by young people must also be taken into account. Many young adults receive the national minimum wage, e.g., in Latvia the largest share of employed young people who receive the minimum wage, or even less, for paid work is among young adults aged 20-24 years. In 2019, this indicator reached almost $25 \%$ of the total number of employed persons. More than $15 \%$ of all young adults employed in the age groups of 25-29 and of 30-34 receive a salary that does not exceed the minimum wage. The minimum wage in each country is shown in Table 2.

Table 2. Monthly Minimum Wage in the Baltic States (EUR)

\begin{tabular}{|l|l|l|l|}
\hline Country & Latvia & Lithuania & Estonia \\
\hline Minimum wage & $430 €$ & $555 €$ & $540 €$ \\
\hline
\end{tabular}

Young adults often work part-time because they also study. Irrespective of whether young people study alongside employment or not, many young people have difficulty in finding suitable housing while receiving such low wages. Inability to get education, to integrate into society, to get a job with a suitable wage are problems that young people face before getting a dwelling. Without access to higher education or the labour market, the difficulty of entering the housing market will increase significantly.

For most households, the labour market is the source of past, present and future income. It is, therefore, important in shaping both perceptions and the reality of housing market decisions (Burke, et al. 2007). Younger generations across a wide range of societies face increasing difficulties in gaining access to housing. Housing occupies a pivotal position in the transition from parental dependence to adult independence. Delayed independence has significant implications for marriage and family formation, fertility, inter- and intra-generational tensions, social mobility and social inequalities (Forrest, Yip, 2012) and it is proven that housing and community problems can significantly affect citizens' health and well-being (Martin, Platt \& Hunt 1987). Living with ongoing stress contributes to health problems as well as placing stress on family relationships. An increased probability of financial hardship can result in young person missing out on school activities and adequate health and dental care, or having to pawn possessions for financial viability (Burke, et al. 2007) and poor housing conditions are associated with a wide range of health conditions, including respiratory infections, asthma, lead poisoning, injuries, and mental health (Krieger, Higgins, 2002). For young adults, as for the 
general population, the cost and quality of housing are determinants of living standards and well-being.

\section{RESEARCH FINDINGS}

Affordable housing is important for the mobility of the population, especially for young people, who often have to change jobs and move in order to find the best employment or educational opportunity. More young adults choose to spend more time in education before entering the labour market, as higher level of education is increasingly perceived as providing better job opportunities and housing.

Summarising the main problems that affect the availability of housing for young people, it can be concluded that the availability of housing is affected by five main factors:

1. The current housing policy is not aimed at increasing the living space;

2. Rising prices in the rental housing market significantly reduce the opportunities of affordable housing for young adults;

3. Young adults are not integrated into the labour market (Jaunatnes starptautisko programmu aǵentūra, 2019);

4. A lot of young adults cannot afford higher education (Karnìte, 2017);

5. A lot of young adults are not able to create financial savings for the purchase of housing (for the first mortgage down payment), because in the current situation they receive a relatively low salary and spend more than $40 \%$ of total household income on housing costs (Eurostat statistical database, 2018).

As the main solutions for increasing the availability of housing for youth, four solutions are pointed out:

1. Integration of young people into the labour market (including social inclusion).

This can be done by raising the skills of young people in the chosen work position and in working with different technologies, developing young people's social skills, as well as developing various projects for integrating young people into the labour market. As one of the examples of such projects, the Rotterdam project "Bridge" can be mentioned that allows for the transition of young people from studies to the labour market.

2. Increasing the availability of education.

It can be achieved by increasing the number of state-funded study programmes, offering affordable housing to young people during their studies, as well as increasing the amount of state scholarships.

3. Increasing youth involvement in housing policy issues.

4. Increasing the available housing stock (including the construction of social buildings for young people).

The EU housing policy should focus on the availability of decent housing in a secure environment. Ways to increase the availability of housing include: improving the energy efficiency of buildings, supporting young adults to buy or build housing, renovating social housing and building new social housing, and creating an effective legal framework for the housing market. Housing policy in 
Latvia is not focused on the construction of social housing. However, social housing construction projects have been successful in several EU countries, e.g., in Poland, France and Norway.

\section{CONCLUSIONS}

The availability of housing is affected by a variety of aspects, so its evaluation and analysis must take into account many factors that affect it both externally and internally. A developed and well-defined housing access policy is necessary to promote the quality of housing and its accessibility for young people by increasing residential areas and ensuring their availability. Providing affordable housing for young people requires an efficient, competitive construction industry with low construction costs, affordable land prices, various types of subsidies and the construction of social housing. Increasing the availability of housing for young people is a very important aspect during the start-up phase of young people's independent living. Helping young people can have a positive effect on their level of education, employment, and overall living conditions. Therefore, it is concluded that:

1. In today's society, the transition of young people to live in their own dwellings is often a complex process due to the interrelated nature of the housing market and youth income inequality;

2. The availability of housing depends on many factors, both internal and external. Political, economic, and socio-economic factors play a key role. The legacy of existing housing policies, social change and social welfare policies have a significant impact on housing affordability and housing policy;

3. The level of education and the availability of work are among the main factors in the availability of housing. However, employment for young people cannot be successful without prior access to stable, secure and suitable housing;

4. Young people with a lower level of education are at greater risk of being excluded from the housing market.

Therefore, the following proposals have been developed:

1. Housing policy should focus on increasing the availability of housing for different social groups, including young people, young families and older people of retirement age;

2. Education and training of young people and programmes for their integration into the labour market offer opportunities for employing more people, focusing on better functioning and less fragmented labour markets, better skilled workforce, better quality and working conditions, and job creation and demand;

3. As the main solutions to increasing the availability of housing for youth, four solutions are indicated: Integration of young people into the labour market (including social inclusion); Increasing the availability of education; Encouraging youth involvement in housing policy issues; Increasing the available housing stock. 


\section{ACKNOWLEDGMENT}

This work has been supported by the European Social Fund Project "Strengthening of Academic Staff of Riga Technical University in Strategic Specialization Areas" Nr. 8.2.2.0/18/A/017

\section{REFERENCES}

Adabre, M. A., Chan, A. P., Darko, A., Osei-Kyei, R., Abidoye, R., \& Adjei-Kumi, T. (2020). Critical Barriers to Sustainability Attainment in Affordable Housing: International Construction Professionals' Perspective. Journal of Cleaner Production, 253, Article 119995. https://doi.org/10.1016/j.jclepro.2020.119995

Advocay. (2019). What is affordable housing? Available at https://auma.ca/advocacyservices/programs-initiatives/housing-hub/what-affordable-housing

Affordable Housing Commission (2018). Defining and measuring housing affordability - an alternative approach, 64 .

Aslam M., \& Zull E. I. (2019). Housing Affordability: Measurements and Trends. In: Leal Filho W., Azul A., Brandli L., Özuyar P., Wall T. (eds) Sustainable Cities and Communities. Encyclopedia of the UN Sustainable Development Goals. Springer, Cham. https://doi.org/10.1007/978-3-31971061-7 89-1

Bergenstråhle, S. (2018). How to define, achieve and measure affordability in rental housing, International Union of Tenants overview, 6.

Billari, F., \& Liefbroer, L. (2010). Towards a new pattern of transition to adulthood? Advances in Life Course Research, 15(2-3), 59-75. https://doi.org/10.1016/j.alcr.2010.10.003

Bleyer, W. A., Albritton, K. (2003). Definition of Older Adolescent and Young Adult. In: Kufe D. W., et al. (eds) 6th edition. Hamilton, BC Decker.

Burke T., Pinnegar S., Phibbs P., Neske C., \& Gabriel M. (2007). Experiencing the housing affordability problem: blocked aspirations, trade-offs and financial hardships. AHURI Research Paper No. NRV3-9, Australian Housing and Urban Research Institute Limited, Melbourne. https://www.ahuri.edu.au/research/nrv-research-papers/nrv3-9

Cai, Z. (2017). Analyzing measurements of housing affordability. Master's thesis, University of Washington.

EU publications office. (2011). The European Platform against Poverty and Social Exclusion: A European framework for social and territorial cohesion, 33. https://eur-lex.europa.eu/legalcontent/LV/TXT/HTML/?uri=CELEX:52010DC0758\&from=EN

Eurostat statistical database. (2018). Housing statistics. https://ec.europa.eu/eurostat/statisticsexplained/index.php?title=Housing_statistics/lv\#M.C4.81jok.C4.BCu pieejam.C4.ABba_cenu zi.C5.86.C4.81 (in Latvian)

Eurostat statistical database. (2019). Current market rents https://ec.europa.eu/eurostat/documents/6939681/7243182/Booklet_2020_rents_2019_e.pdf/c7 7c6c5a-48e4-0ed3-424a-02bcc99a2e7e

Erikson, E. H. (1975). Childhood and Society, Penguin Books.

Gopalan, K. \& Venkataraman, M. (2015). Affordable Housing: Policy and Practice in India. IIMB Management Review, 27(2), 129-140. https://doi.org/10.1016/j.iimb.2015.03.003

Forrest, R., \& Yip, N. M. (2012). Young people and housing: Transitions, trajectories and generational fractures. 1st ed. Routledge. https://doi.org/10.4324/9780203095096

Gan, Q., \& Hill, R. J. (2009). Measuring housing affordability: Looking beyond the median. Journal of housing Economics, 18(2), 115-125. https://doi.org/10.1016/j.jhe.2009.04.003

Jaunatnes starptautisko programmu aǵentūra. (2019). Jauniešu labbūtība Baltijas valstīs: Pētījuma ziņojums (Latvija), Projekts “Jauniešu dzīves kvalitātes izpēte Baltijas valstīs", 74.

Karnīte, R. (2017). Latvijas Zinātṇu akadēmijas Humanitāro un sociālo zinātṇu nodaḷas slēdziens, Jauniešu bezdarbs - cēloni un risinājumi, 91.

Krieger, J., \& Higgins, D. L. (2002). Housing and Health: Time Again for Public Health Action. American Journal of Public Health, 92(5), 758-768. https://doi.org/10.2105/AJPH.92.5.758 
Linneman, P., \& Megbolugbe, I. F. (1992). Housing Affordability: Myth or Reality? Urban Studies, 29(3/4), 369-392. https://doi.org/10.1080/00420989220080491

Martin, C. J., Platt, S. D., \& Hunt, S. M. (1987). Housing conditions and ill health. Br. Med. J. (Clin. Res. Ed.), 294, 1125-1127. https://doi.org/10.1136/bmj.294.6580.1125

Mohan, R. (1992). Housing and Urban Development: Policy Issues for 1990s. Economic and Political Weekly, 27(36), 1913-1920. Retrieved January 12, 2021, from http://www.jstor.org/stable/4398847

Munson, M. R., Stanhope, V., \& Small, L. (2017). "At times I kinda felt I was in an institution": Supportive housing for transition age youth and young adults. Children and youth services review, 73, 482-436. https://doi.org/10.1016/j.childyouth.2016.11.027

OECD Affordable Housing Database. (2019). Housing-related expenditure of households, OECD publishing, 7.

Peter, K. M. (2016). Young people and housing: identifying the key issues. International Journal of Housing Policy, 16(2), 137-143. https://doi.org/10.1080/14616718.2016.1159273

Pittinii, A. (2012). Housing affordability in the EU - Current situation and recent trends. CECODHAS Housing Europe's Observatory, Research Briefing, Year 5, No. 1.

Schelkshorn, D. (2018). Young Adults and Transitional Housing Arrangements in the City of Amsterdam. MSc Thesis Project in Urban Geography, University of Amsterdam, 67. p.

Stephens, M., Fitzpatrick, S., Elsinga, M., Van Steen, G., \& Chzhen, Y. (2010). Study on housing exclusion: Welfare policies, housing provision and labour markets. European Commission/University of York.

Stone, M. E. (2006). Housing Affordability: One Third of a Nation Shelter-Poor. Community Studies Faculty Publication Series. 5. Retrieved January 12, 2021, from https://scholarworks.umb.edu/communitystudies_faculty_pubs/5

\section{AUTHORS' SHORT BIOGRAPHIES}

Eliza Sekace has finished both Bachelor and Master studies at the Faculty of Engineering Economics and Management, Riga Technical University (Latvia). She has a master's degree in real estate management and civil construction and currently she is a student in Master study programme Entrepreneurship and Management at Riga Technical University (Latvia).

E-mail: elizasekace@gmail.com

Janis Viesturs, Mg. oec., is a Researcher at the Faculty of Engineering Economics and Management, Riga Technical University (Latvia). Janis Viesturs has more than 25 years of experience in real property management, development, transactions and due diligence process. He is lecturing the course "International Real Estate Transactions". Since 2015 he has participated in scientific conferences, congresses and workshops. His research interests cover real property definition, international and national real property transactions, different real property registration systems, real property due diligence process and real property management. He is a $\mathrm{PhD}$ student at RTU.

E-mail: janis.viesturs@rtu.lv

ORCID iD: https://orcid.org/0000-0002-0267-1858 